\title{
AUTORITARISMO E DISCURSO LITERÁRIO
}

Jurema José de OLIVEIRA ${ }^{1}$

Um escritor não é um homem escritor, é um homem político, e é um homem máquina, e é um homem experimental (que deixa assim de ser homem para se tornar símio, ou coleóptero, ou cão, ou rato, tornar-se-animal, tornar-se-inumano, pois na verdade é pela voz, é pelo som, é por um estilo que se torna animal, e seguramente por força de sobriedade).

(DELEUZE e GUATTARI: 1977, p.13)

O objetivo deste trabalho é detectar as marcas de um sistema político autoritário, que postula o princípio da autoridade para silenciar a liberdade individual, nas obras: A hora dos ruminantes (1969), de José J. Veiga, e Maio, mês de Maria (1997), de Boaventura Cardoso. A escrita de ambos os textos cria símbolos que reinterpretam alegoricamente a censura imposta no Brasil na época da ditadura e em Angola no período do fraccionismo. A primeira obra divide-se em três partes: a chegada, o dia dos cachorros e o dia dos bois e a segunda em trinta e quatro capítulos.

$\mathrm{O}$ estilo discursivo que norteia as narrativas de A hora dos ruminantes (1969) e Maio, mês de Maria (1997) oscila entre a paródia e a alegoria. A paródia procura dar conta dos procedimentos necessários à configuração do trabalho artístico, depreendendo categoricamente lugar e voz dos enunciados, assim como a temática e a rede figurativa que ela põe em jogo na história que os romances contam. A alegoria expõe por sua vez um pensamento que representa determinada situação, mas pretende dizer de fato outra coisa. A obra de arte procura dizer o real, ainda que subjetivamente, como o real procura se dizer por meio da obra de arte. Desta forma, cada um diz o outro e se diz no outro alegorica-

1.Doutora em Letras / UFF - Universidade Federal Fluminense - Niterói / Brasil. 
mente falando. Assim, com o intuito de abarcar a totalidade das coisas, ela funciona como o fio condutor na busca da "essência escondida" (GENETTE: 1972, p.45). Logo, as frases precisam ter uma consistência semelhante àquela presente nos objetos representados, mas isso não significa que a representação possa atingir exatamente o objeto desejado.

A alegoria tende a ser a linguagem da subversão, pois aponta para a mudança da ordem estabelecida e corresponde ao afloramento do reprimido na história. $\mathrm{O}$ objeto alegórico funciona como o índice da história que poderia ter sido, mas não foi ao denunciar a repressão. Ele efetiva assim uma distância entre o significante e o significado, pois se refere ao "outro" numa alusão pluralista.

De acordo com Orlandi (2002, p.85), a escrita literária permite o distanciamento da vida cotidiana, a suspensão dos acontecimentos. Ela faz circular outros sentidos pela técnica de deslocamento, já que as marcas discursivas apagadas pela censura na vida diária e a falta de heterogeneidade identitária se traduzem numa asfixia típica do autoritarismo, pois "não há reversidade possível no discurso, isto é, o sujeito não pode ocupar diferentes posições: ele só pode ocupar o 'lugar' que lhe é destinado, para produzir os sentidos que não lhe são proibidos" (ORLANDI: 2002, p.81). Essa produção discursiva fundamenta-se na relação parafrásica, isto é, na reprodução daquilo que pode ser dito num discurso prolixo sem alteração de sentidos. $\mathrm{O}$ autoritarismo impõe pelo poder, pela força, um sentido único para toda a sociedade, mas por outro lado, abre espaço para o surgimento de mecanismos que "explode[m] os limites do significar" (ORLANDI: 2002, p.87), via metáforas.

$\mathrm{O}$ escritor utiliza em um regime ditatorial elementos díspares para produzir os novos significados. Desta forma, o material oriundo da linguagem cotidiana passa por transformações para emitir novos sentidos no discurso literário. Esses efeitos se processam numa linguagem que 
tem seus contornos iniciais modificados pela reinterpretação. Assim, Amâncio, o comerciante de Manarairema, do romance A hora dos ruminantes (1969), tem a incumbência de intermediar as questões entre os cidadãos da cidade e a "gente estranha", que trouxe "dor de cabeça" à comunidade: "Amâncio, agora, era uma espécie de advogado dos homens" (HR: p.39).

O outro elo era aquele existente entre Serrote, o cavalo, e Geminiano, o dono da carroça puxada por Serrote, pois eles prestam serviços tanto para os homens da tapera como para a população local. A palavra serrote dicionarizada significa cortar, separar e adquire no romance mais uma acepção, pois pode ser lida, também, como um divisor de águas "pesadas, profundas e escuras" (BACHELARD: 1998, p.47). Serrote corta a cidade puxando "aquela carroça que era utensílio público" (HR: p.47). Ele se desloca de "cabeça baixa, num conformismo inconformado, [...] procurando no chão a justificativa para aquele trabalho absurdo, idiota" (HR: p.29).

O trabalho "idiota" consome, corrói Serrote e o cavaleiro Geminiano, "antes tão confiante e desempenado [...], agora aquilo - um homem desmanchado na boleia, os ombros despencados, os olhos fixos nas ancas cada vez mais magras de Serrote, despreocupado do caminho" (HR: p.29). As frases curtas, objetivas são ampliadas pelo acúmulo de significação, que parte de uma relação objetiva entre a significação própria e a figurada para demarcar a falta, a negação de sentidos nas ações dos personagens. José J. Veiga - com o intuito de explorar ao máximo os efeitos de repressão em Manarairema e explicitar a imobilidade discursiva - usa verbos que denotam a degradação de ambos os personagens.

Geminiano desumanizou-se, igualou-se ao cavalo gradualmente, pois está se "desmanchando", se "despencando". Esses e outros verbos diluem a noção de movimento crescente da palavra precisa, exata com 
a qual o sujeito faz e encontra sentido. As informações contidas nessa linguagem reinterpretam a ausência de diálogo entre o grupo (cidadãos manarairenses) e os outros, (aqueles engravatados) que alteraram a engrenagem da cidade: "O tempo passava e nada mais acontecia [...]. Das intenções dos homens, da sua ocupação verdadeira a cidade continuava na mesma ignorância do primeiro dia” (HR: p.31).

A censura apaga os limites entre os projetos individuais e coletivos, neutralizando as ações do "eu - pessoal” e do "eu - político"; cumpridor das ordens estabelecidas; massifica; oculta; silencia todo e qualquer sentido diferenciador; mantém um discurso permanente, aposta no discurso do mesmo. As vozes silenciadas na vida real pelo processo de apagamento produzido pela censura ressoam na obra de José J. Veiga e de Boaventura Cardoso. As narrativas trazem no corpo do texto circunstâncias como práticas violentas e violadoras dos direitos humanos, elas transpõem o que foi recalcado, silenciado para o espaço do contado, que redimensiona os fatos. Os produtores de discursividade buscam explodir os limites impostos e expurgar um discurso conhecido e reconhecido - monológico por natureza - ao narrarem as histórias de personagens fictícios que simbolizam uma coletividade. Sendo assim, escolhendo o polissêmico, o diferente; essas narrativas dizem "o mesmo para significar outra coisa" (ORLANDI: 2002, p.98) e dizem "coisas diferentes para ficar no mesmo sentido" (ORLANDI: 2002, p.99).

Do ponto de vista estético, a linguagem de Maio, mês de Maria articula um falar culto com um falar coloquial. As frases são entrecortadas ora por expressões locais, ora por estruturas que retomam o português escrito. Num plano figurativo, as descrições familiares traduzem bem a dissonância, a desterritorialização (DELEUZE e GUATTARI: 1977, p.10) da língua e dos falantes, isto é, o isolamento lingüístico que deixa desterrado o indivíduo dentro de seu próprio território. O proces- 
so comunicativo entre emissor e receptor não ocorre em Maio, mês de Maria. As regras que governam as produções lingüísticas ali estabelecidas não levam em conta as diferenças sociais, logo não há interação.

Toda comunicação discursiva só adquire valor se realizada no contexto social e cultural apropriado. A construção dos atos de linguagem precisa levar em conta as relações sociais entre o falante e o ouvinte. Os produtores do discurso precisam conhecer e agir verbalmente de acordo com determinadas regras para a produção discursiva ser completa, isto é, eles precisam 'saber’: “a) quando pode falar e quando não pode; b) que tipo de variedade lingüística é oportuno que seja usada" (GNERRE: 1998, p.10).

Esses elementos constituem a base condizente com o ato de fala propriamente dito e deverão estar de acordo com o contexto em que o ato verbal será produzido. A presença de tais códigos torna-se um dado positivo não só para o falante, mas também para o ouvinte que pode ter alguma expectativa em relação à produção lingüística do falante, distinta daquela estabelecida na cerimônia de casamento. De um lado, encontra-se a família de Hortência: "gente de posição média [...] instruída" (MMM: p.54) e do outro lado, com menos instrução e menos "elegância", os familiares do noivo. O contraste, o choque cultural é explicitado pelo conflito instaurado na língua dos desterrados do Bairro do Balão e, especialmente, na festa de casamento. Os signos recebem uma nova configuração nos falares que estavam para acontecer:

- Meus senhores e minhas senhoras. Eu aqui presente, Chitalu Sipanguale, tio do camarada Comandante, quer falar uma cueza na noiva e no noivo meu sobrinho camarada Comandante, calem a boca, porra! [...], silêncio! _ mas quem que mandou este sacana falar, João Segunda estava pensar no íntimo dele _ eu aqui presento Chitalu Sipanguale quero desejar os noivo ficam bem, ficam felizes, quando tiver discutissão lá em casa 
é só chamar de mim ou o compadre nome dele João Segunda para resolver os problema, vocês devem ter muitos filios, os filios é a riqueza dos pobres (MMM: p.53. Grifos nossos).

O discurso do Chitalu intensifica as disparidades, a confusão de signos deslocados com uma sonoridade destoante que se traduz em diferenças discursivas e de classes sociais. Esse dado aparece no contexto narrativo como mais um elemento para referendar a idéia do sujeito desterrado, isolado num cenário opressivo, sanguinário, de medo e de sombra infiltrado nos 'falares' e nos 'lares': “quem que imaginava nos tempos agora nossos a gente tinha de retrazer memória esquecida do tempo do tuga, vigiar a palavra, reaprender a pose estudada na esquina do olhar pidesco? (MMM: p.84).

\section{A fúria canina e a hora de Maria}

O discurso dominante fundamenta-se em signos marcados pela superposição de dados. Esses elementos representam uma única verdade, dotada de recursos retóricos que têm como finalidade convencer ou alterar atitudes e comportamentos já estabelecidos. Os cachorros redimensionam a vida de Manarairema:

A cidade estava engrenando na rotina do tomar café, do regar horta, do varrer casa, do arrear cavalo, quando os latidos rolaram estrada abaixo. [...] Borboletas inocentes [...] morreriam [...] pisadas, mordidas, desmanchadas como flores depois da ventania. O palco estava armado para os cachorros, e eles o ocuparam como demônios alucinados (HR: p.34-5).

As ações repressivas, típicas da ditadura são simuladas pelos animais que representam os homens que viviam na tapera de forma enigmática "entocados lá longe, cercados, fechados" (HR: p.40). Os signos que demarcam a dominação fixam o jogo demoníaco em Manarairema: "toda a cidade estava praticamente a serviço dos cachorros tudo o mais parou" (HR: p.37). A contaminação contextual é recontextualizada, explicitada por meio de expressões específicas do tipo: "pêlo suado, urina concentrada, 
estrume pisado" (HR: p.35). As marcas dispersas na cidade eram dos animais. E na impossibilidade de redimensionar a vida, de trazer de volta o "descanso", o "sossego" e novos sentidos que fossem "apreensíveis, verbalizáveis" (ORLANDI: 2002, p.35), os manarairenses procuram se adaptar a nova situação: "De repente ficou parecendo que todo mundo adorava cachorro, quanto mais melhor, e só tinha na vida a preocupação de fazê-los felizes" (HR: p.36).

A imagem canina impulsionadora da trama de A hora dos ruminantes está presente também em Maio, mês de Maria. Num processo alegórico, a fúria canina se desenrola na procissão de Nossa Senhora de Fátima, padroeira do Bairro Balão. Os símbolos religiosos abarcam potencialmente a dinâmica estrutural que configura a idéia de fé na santa padroeira, mas também outra, a ideológica, que motivou no passado os guerrilheiros de Mayombe, por exemplo, e agora absorve as idéias de jovens, que querem "voar liberdades". O medo marca o código lingüístico, a palavra dita passa por um polimento "censório" e se enche de outros significados. Por isso: "o coração se enchia de muitas palavras que acabavam por não nascer" (MMM: p.177) e só encontravam reforços nas preces à Nossa Senhora de Fátima, pois os homens e mulheres "fervorosos" se alimentavam "candidamente na esperança e no amor" (MMM: p.177).

O narrador oscilando entre um português polido, culto e a perspectiva de João Segunda, de forma metonímica, usa termos que ora anunciam uma procissão religiosa, ora uma manifestação política. E é nesse universo alegórico que os cães deixaram suas marcas, na cena que é recuperada de modo oralizado pelas interjeições que dinamizam o contado que quase salta do escrito para o oral:

Olharam para trás e pararam e não viram nada.[...] Daí a pouco puderam então ver, apesar de já estar a escurecer, uma grande 
matilha de cães a vir atrás da manifestação.[...]. Em poucos minutos estavam todos manifestantes, cerca de um milhão, a fugir em debandada.[...] rapazes a treparem árvores, crianças perdidas a chorarem desesperadas, aleijados a gritarem por socorro me levam só nas costas!, quem que lhes ligava?, gente a desmaiar em cadeia, Eh!Eh!Ehé!, dezenas de velhos se arrastarem exangues no asfalto, mulheres grávidas na iminência de parirem se esvaindo em sangue. Na confusão, uns que aproveitavam ainda para roubar. Ehé! Ehé! Ehé! [...] Pouco depois, na rua só estavam já os quatro homens que transportavam o andor e sô Padre que se manteve serenoso. Entretanto, os latidos se tinham deixado de ouvir, mas os cães vinham às centenas, se aproximando. Eh! Homens que transportavam o andor deram meia volta e puseram a Santa voltada para os cães [...], a Santa falou assim: VINDE EM PAZ! Que ela falou altíssonante! Eh! Eh! Eh! Todo mundo ouviu a Santa falar aquelas santas palavras (MMM: p.227-8).

Num processo fantasmagórico, a paz de repente foi estabelecida mais uma vez pela fé que transforma, revigora num plano outro, energizado pelos "corpos jazidos no asfalto [que] estavam se movimentar sozinhos" (MMM: p.228). Nesse cenário extraordinário os "cães começaram estavam se transformar em homens, bons cristãos" (MMM: p.228). As imagens migram, se transformam, para dar conformidade às situações disformes, presentes em Maio, mês de Maria. Os signos reordenados corporificam as leis, proibições e restrições, que determinam o sistema e a ordem da vida dos animais que sofreram uma metamorfose.

Num processo de reinterpretação dos fatos, a linguagem de Maio, mês de Maria se superpõe a "desconfiança", ao "medo que estava se infiltrar em todos os lares" (MMM: p.84). O narrador procura depreender formações discursivas díspares, dicotômicas, cujos significados se distanciaram por força das circunstâncias da significação dicionarizada. As ações caninas se assemelham às atitudes humanas, às práticas militarizadas de um sistema totalitário. Na impossibilidade de identificar 
o inimigo, de localizar os responsáveis pelas atrocidades, os moradores do Bairro do Balão ouvem os "rumores" e tentam se defender dos "cães sanguinários" que "atuavam sozinhos".

\section{Conclusão: repetições e rumores}

Em Maio, mês de Maria, os signos lingüísticos reformulados ora delimitam, ora expandem os significados. A arbitrariedade desses sinais pode ser interpretada como um jogo retórico de idéias, gritos que escapam à significação "vigiada", "refreada" e contaminada por "espalhar o terror e a morte" (MMM: p.84).

Aspectos como o comportamento, os gestos contidos, as repetições de palavras, cujas conotações demarcam os vários sentidos reprimidos, encenam a alegoria dos valores, idéias, fenômenos e coisas combinadas em um contexto de ansiedade "expectante", de "antivisões alucinantes em noites de febres altas, tensões, emoções, sincopadas" (MMM: p.171). Gradualmente, a sonorização dos signos se traduz metaforicamente em murmúrios produzidos por personagens agitados, assustados e insatisfeitos como: "João Segunda [que] não sabia bem como agir. Que estava pensar qualquer atitude dele podia ser mal interpretada e então lhe fazerem outra vez desaparecer" (MMM: p.84).

Em "o dia dos bois", terceira parte de A hora dos ruminantes, as ações dos ruminadores são instintivas, animalescas, metáfora da inumanidade de "homens perversos" que lembravam "bois com cara de animais medonhos [...], soltando berros que pareciam gargalhadas" (HR: p.93). A figura bovina representa a repressão. A idéia de domínio, de controle do espaço se processa na massificação, na multiplicação dos animais: “os bois [foram] aparecendo aqui, ali, nas encostas das serras, nas várzeas, na beira das estradas, uns bois calmos, confiantes, indiferentes" (HR: p.83). Do dia para a noite, as réplicas dos ditadores tornaram inacessível a vida 
dos "manarairenses [que] só tinham de esperar e confiar. Se as paredes resistissem e os mantimentos durassem em breve o povo estaria nas ruas festejando a recuperação de sua cidade" (HR: p.86).

Os sinais reificados articulam, agrupam os ruminantes no conjunto das similaridades, limitando, inibindo a formação de novos significados. Nesse contexto, "o signo se fecha e irrompe na voz da 'autoridade' [...]. O discurso autoritário lembra um circunlóquio: como se alguém falasse para um auditório composto por ele mesmo" (CITELLI: 1991, p.39).

A igreja em A hora dos ruminantes se apresenta de forma estática, sem mobilidade, desprovida da persuasão que lhe é inerente. O discurso religioso foi anulado, silenciado, e o veículo de Deus tornou-se um ser pasmado, imóvel: "O bom padre coçava a cabeça, olhava o campo de chifres espalhado em frente, prometia pensar no assunto. Por fim ele fechou a janela e foi olhar a sua coleção de selos" (HR: p.87). Em contrapartida, a igreja em Maio, mês de Maria cumpre bem o seu papel, chegando até a simular a materialização da santa. A voz da Virgem Maria plasma "todas as outras vozes, inclusive a daquele que fala em seu nome: o (padre)" (CITELLI: 1991, p.48).

O discurso religioso efetiva, assim, o processo autoritário por meio da repetição de orações e ladainhas, que compõem a procissão, pois "repetir significa a possibilidade de aceitação, pela constância reiterativa" (CITELLI: 1991, p.48), da visão dogmática que tem como objetivo englobar todas as falas do rebanho: "É milagre, os jovens que pensaram. E então muitos que puderam ver no céu avermelhado imagem de Virgem resplandecendo, rosto expressivo melancólico, talvez triste" (MMM, p.167). A imagem que desponta num "céu [...] vermelho da cor do sangue" (MMM, p.167), diante de João Segunda, todo mordido pelos "cães raivosos", observa num plano alegórico um acontecimento histórico, o fraccionismo, ocorrido em 1977. 
De acordo com Jakobson, este movimento de transmutação das coisas por meio da repetição se traduz na ficção como poética da linguagem. Poética esta que abre caminho para o "apuramento" dos fatos, da sua significação elaborada pelo sujeito do discurso que por meio de "apontamentos" vai delineando a "face obscura" do nascimento do "homem novo" às avessas, já que Finisterra era um "micromundo" dos vivos/mortos, de riachos secos, de dias e noites agitados para aqueles que foram retirados do Bairro do Balão.

O jogo metafórico, estabelecido pela voz da enunciação, encontra reforço nas imagens estratificadas da violência e da violação, embutidas nas ações dos personagens (OLIVEIRA: 2007, p.156). Boaventura Cardoso cria, na ficção, uma "proposição de verdade" para o 27 de maio de 1977, usando recursos estilísticos do tipo de conectores como o "que", o "e", o "assim" e outros, várias vezes em um mesmo parágrafo, para estabelecer na seqüência narrada uma semelhança semântica de idéias; de verbos repetidos nas seqüências oracionais definidoras de um tempo relembrado pelo narrador, por exemplo, quando deseja informar como deve se comportar o Presidente João Segunda em Finisterra, além de informar no enunciado que o personagem "Segunda" tem que metaforizar o "linguajar", usado nos tempos de "perigo" iminente.

Esta situação pode também ser remetida à idéia que caracteriza a repetição - um acontecimento ocorrido no passado e que ocorre "de novo" -, isto é, a experiência histórica dos campos de concentração retorna no tempo do fraccionismo narrado em Maio, mês de Maria, como se pode perceber na fala do narrador, ao destacar os procedimentos que João Segunda deveria seguir com a ajuda do enfermeiro sô David:

Com o tempo se foi familiarizando com a gente da comuna, embora prudente conforme lhe tinham aconselhado É que, sô David lhe revelou, tinha no seio da população muita gente sem escrúpulos que não se 
importava de falsear verdades a troco de dinheiro. Depois, tinha outro perigo: João Segunda não era da região e por isso não falava a língua local. Quando que falava com as pessoas da comuna, tinha de linguajar as simples falas directas. De outro modo seria logo tido como branco, apesar da cor que ele tinha. Para ocupar o tempo, Segunda jogava às cartas com sô David e lhe ajudava no tratamento dos doentes dele. Coisas simples: limpar feridas com tintura de iodo, fazer pensos e atar ligaduras, esterilizar, fervendo, agulhas e seringas. Tinha também vezes de irem caçar nas matas de Sandundo, Kapalandande ou Kafuana, ou de pescarem os saborosos peixes na lagoa Tchimbetcha. Entre ele e o enfermeiro foi nascendo assim uma grande e sincera amizade. Sô David vivia profundamente as preocupações dele, por isso tentava sempre lhe ajudar. Segunda que confirmou provado: enfermeiro David era um amigo e tinha humanismo no trato com toda gente (MMM: p.161. Grifos nossos).

A imagem na citação revela as contradições resultantes de um contexto heterogêneo, mas silenciado por força de um discurso monológico, estabelecido pelos compatriotas do Bairro do Balão que negam veementemente qualquer movimento diferente, ou seja, qualquer ação capaz de lembrar a idéia de diálogo para se chegar a um acordo amigável, pois

Tinha gente era pela destituição de João Segunda por incompetência e corrupção. Tinha outra gente estava falar lhe fosse dada mais uma oportunidade, até não era muito grave o que dele se dizia, ele até tinha feito algum trabalho, tinha muita intriga no meio de tudo aquilo, tribalismo porque ele era do Kwuanza Sul, tinha chegado a hora de os sulanos também mandarem no Bairro do Balão que era considerado um bairro de todos (MMM: p.175. Grifos nossos).

Assim, a repetição funciona como um expressivo mecanismo lingüístico. Num primeiro momento - na estrutura oracional ou frasal este sistema tende a funcionar "como recurso para a valorização de por- 
menores do texto" (OLIVEIRA: 1999, p.235), transformando-os em seguida numa eficiente fórmula de ampliação temática que se efetiva, de fato, pelas imagens superpostas para conferir aos livros aqui estudados uma nova estética literária e um novo paradigma, gerador de uma reflexão crítica acerca de situações violentas que violam os direitos humanos. Tais obras acabam por refletir um "espelhamento" dos contextos sociais representados na ficção.

\section{Referências}

BACHELARD, G. A água e os sonhos: ensaio sobre a imaginação da matéria. São Paulo: Martins Fontes, 1998.

CARDOSO, B. Maio, mês de Maria. Porto: Campos das Letras, 1997.

CITELLI, A. Linguagem e persuasão. 6ed. São Paulo: Ática, 1991.

DELEUZE, G. e GUATTARI, F. Kafka: por uma literatura menor. Rio de Janeiro: Imago, 1977.

GNERRE, M. Linguagem, escrita e poder. 4ed. São Paulo: Martins Fontes, 1998.

OLIVEIRA, H. A. A linguagem em A hora da estrela: uma análise sintático-semântica. Tese de Doutoramento. Niterói: UFF, 1999.

OLIVEIRA, J. J. Violência e violação: uma leitura triangular do autoritarismo em três narrativas contemporâneas luso-afro-brasileiras. Luanda: União dos Escritores Angolanos / UEA, 2007.

ORLANDI, E. P. As formas do silêncio: no movimento dos sentidos. 5ed. Campinas: Unicamp, 2002.

VEIGA, J. J. A hora dos ruminantes. 2ed. Rio de Janeiro: Civilização Brasileira, 1969. 